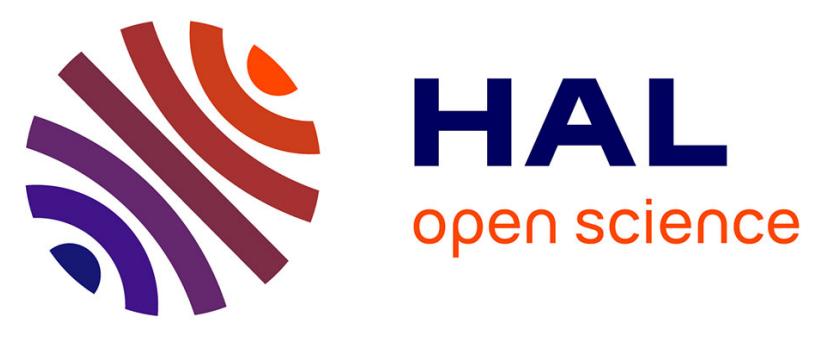

\title{
Semantic prosody and specialised translation, or how a lexicogrammatical theory of language can help with specialised translation
}

\author{
Natalie Kübler, Alexandra Volanschi
}

\section{- To cite this version:}

Natalie Kübler, Alexandra Volanschi. Semantic prosody and specialised translation, or how a lexicogrammatical theory of language can help with specialised translation. Alex Boulton, Shirley CarterThomas, and Elisabeth Rowley-Jolivet. Corpus-informed Research and Learning in ESP: Issues and Applications, John Benjamins Publishing Company, pp.105-135, 2012, Corpus-informed Research and Learning in ESP: Issues and Applications. hal-01134920

\section{HAL Id: hal-01134920 \\ https://hal-univ-paris.archives-ouvertes.fr/hal-01134920}

Submitted on 24 Mar 2015

HAL is a multi-disciplinary open access archive for the deposit and dissemination of scientific research documents, whether they are published or not. The documents may come from teaching and research institutions in France or abroad, or from public or private research centers.
L'archive ouverte pluridisciplinaire HAL, est destinée au dépôt et à la diffusion de documents scientifiques de niveau recherche, publiés ou non, émanant des établissements d'enseignement et de recherche français ou étrangers, des laboratoires publics ou privés. 
Semantic prosody and specialised translation, or how a lexicogrammatical theory of language can help with specialised translation

Natalie Kübler \& Alexandra Volanschi

\begin{abstract}
Corpus linguistics has invaded translation studies and practice over the last fifteen years, allowing researchers to analyse the language of translation or to use corpora as tools in the translation process. This study deals with the application of a theoretical and methodological corpus linguistics approach to pragmatic translation, more precisely with the analysis of semantic prosody in a contrastive study both between French and English, and between general and specialised language. The data confirm that semantic prosody does not present a univocal matching between two languages. Moreover, the study demonstrates the need for corpus data over intuition to understand the fluctuation of semantic prosody between general language and languages for specific purposes. Finally, the question of translation based on corpus data will be addressed.
\end{abstract}

Key words:

Semantic prosody, English, French, general language, languages for specific purposes, specialised translation, pragmatic translation

\title{
1. Introduction
}

This paper tackles the issue of semantic prosody in a pragmatic translation environment. The term "pragmatic translation" encompasses what is generally called "specialised translation", which is usually opposed to literary translation. We prefer the term pragmatic translation to avoid the disjunction between literary and specialised translation. Pragmatic translation has been defined by Newmark (1988) as a process taking into account the intent of the author and the expectations of the reader, but also the perlocutionary effect it has on the reader. It is also concerned with the translation of texts pertaining to specific genres such as user manuals, scientific papers, marketing texts, etc., and specialised domains such as engineering, finance, law and sciences for example. Semantic prosody, on the other hand, is linked with notions such as connotations (Stubbs 2001), attitudinal meaning (Sinclair 1987), or evaluative meaning (Hunston 2007), and deserves further study for its effects on pragmatic translation, and thus on the translation of specific genres and specialised texts.

In the last fifteen years, corpus linguistics has invaded translation studies in providing tools to help in the translation process, corpora and methodologies to extract terminology, and also in raising the awareness of translation students (and future professional translators) to the lexico- 
grammatical environment of words, i.e. to collocational phenomena and to what Sinclair (1991) calls the collocational profile of words. As Stewart (2009: 29) says:

\author{
semantic prosody must be seen as a reality that translators \\ are required to address, otherwise important source text \\ elements will be left unaccounted for.
}

This paper proposes therefore to study semantic prosodies in a comparable English/French corpus of specialised texts in earth science to detect potential sources of difficulties, and to show how corpus linguistics methods can help translators avoid collocational pitfalls (Kübler et al. 2010). As semantic prosodies are difficult to detect automatically, we will start with items already described by various authors, and check whether they are valid in languages for specific purposes (LSP). Analysing the macro- and micro-context around those items will help us find regular patterns which can be used to detect more prosodies that may only exist in LSP.

The semantic prosodies uncovered will also be checked against other general and specialised corpora, in order to verify Tribble's (2000) hypothesis of local prosodies and to detect whether a specific prosody belongs to earth science or to general scientific English (Pecman 2007).

We will start with commit and commettre in general English and French, in order to demonstrate what kind of differences can exist between two equivalents which present an unquestionable negative semantic prosody. We will then extend the methodology to two other verbs which have negative semantic prosody in general language, and which are quite common in earth science, namely, to cause, which has been studied in LSP by Hunston (2007) and Louw and Château (2010), and causer. The comparison between English and French will lead us to further hypotheses concerning the pervasiveness of semantic prosody. Near synonyms of the two verbs in earth science will then be presented (following Partington's [1998] and Bowker's [2007] studies of synonyms) in the light of translation difficulties.

As semantic prosody deals with the evaluative meaning of a segment, and thus operates at the pragmatic level, it seems to be particularly relevant to study it in the field of pragmatic translation studies.

\title{
2. Semantic prosody
}

The concept of semantic prosody was invented by Sinclair (1987), but the term was first coined by Louw in his seminal article (1993) on the basis of Firthian "phonological prosody" in which phonological colouring can transcend segmental boundaries ${ }^{1}$. Thus Louw defines semantic prosody as "a consistent aura of meaning with which a form is 
imbued by its collocates" (1993: 157). Sinclair insists on the fact that semantic prosody is on the "pragmatic side of the semantics/pragmatics continuum" (1996: 87) and is attitudinal. It is situated on the highest level of abstraction in the extended description of the lexical unit: collocation (cooccurrence of a node with a specific word), colligation (cooccurrence of a node with a set of words belonging to a specific syntactic category), semantic preference (cooccurrence of a node with a set of words belonging to the same semantic class, i.e. sharing a set of semantic features), and semantic prosody. For Louw again (2000), semantic prosody is a collocational phenomenon which can be detected by looking for a consistent series of collocates which usually have a positive or negative connotation. This phenomenon has been extensively studied by Stubbs (2001) (who prefers to call it discourse prosody or pragmatic prosody), Partington (1998, 2004), Hunston (2002, 2007), Whittsit (2005), and recently by Stewart (2010) in a very complete and well documented critical evaluation of the phenomenon and the issues and debates it has raised.

Semantic prosody however has been mainly studied in English, and especially in "general" English. Sinclair (1991) for example drew attention to the negative prosody of happen. Louw (2000) studied examples such as bent on, and the double prosody of build up (Louw, 1993), which is positive when used transitively and negative when used intransitively. This demonstrates that the collocational phenomena belonging to the collocational profile of a word can be embedded in each other; here the semantic prosodies of build up are linked to the type of colligation it appears in (build up a vs. build up of). For Stubbs (2001: 198) semantic prosody is strongly related to connotation which can be found in lexical and syntactic units expressing evaluative meanings. Stubbs extensively studies patterns related to the verbs lurk, accost and loiter (2001: 198), the lexico-syntactic construction make one's way somewhere (2001: 206), and the syntactic example of $B E$-passives and GET-passives (2001: 211) demonstrating that semantic prosody appears in different structures of the language.

One of the issues concerning semantic prosody with which we are concerned here is the question raised by Whittsit (2005) about the pervasiveness of semantic prosody. This means that if a lexical item shows semantic prosody in a certain context, the prosody will remain the same in another context, thus colouring the new environment with negative or positive connotation. This is particularly important here, as this pervasiveness can be questioned in LSPs.

\subsection{Semantic prosody in languages for specific purposes}

Few authors have studied semantic prosody in LSP or in different registers. Tribble (2000: 86) argued that "local prosodies" can be established in certain genres, which he demonstrates with the word 
experience in a corpus of European project proposals. Curado Fuentes (2001) studied semantic prosody in academic and technical corpora with a view to ESP development. Hood (2006: 37) analysed the "construction of evaluative stance in the introductions to academic research papers" by looking at how semantic prosodies work. Focussing on business English corpora, Nelson (2006) showed that the phenomenon has a tendency to become more "fixed" in business English than in general English. Partington (1998: 74-75) showed how prosodies can help create attitude in analysing a newspaper corpus. In a more recent article (2004: 154155) he suggested that a lexical unit used in general language can have different semantic prosodies than in specialised language, so that a change of context can modify the attitudinal meaning of a lexical unit. Bowker (2007) compared the collocational profile of identify in the British National Corpus (Davies 2004; henceforth BNC; ) and in a computer security corpus and came to the conclusion that identify tends to occur more in a negative environment in the specialised corpus than in the BNC, which seems to confirm Partington's hypothesis and Tribble's (2000) concept of local prosodies. In a 2007 article, Hunston refined the description of the verb cause, which Stubbs (1995) described as always bearing negative semantic prosody, thus as always followed by items having a negative connotation, such as damage. Hunston (2007: 252) showed with examples selected from New Scientist that cause does not always have negative semantic prosody. We will come back later to this question.

\subsection{Semantic prosody in translation or contrastive studies}

Although semantic prosody has mainly been studied monolingually, and mostly in English, another approach consists in studying it crosslinguistically. Tognini-Bonelli (2001) studied English and Italian semantic prosodies, while Berber Sardinha (2000: 106) did the same for English and Portuguese, demonstrating that semantic prosody of nearsynonyms was unpredictable across languages. Xiao and McEnery (2006) also compared the semantic prosody of near-synonyms between English and Chinese. Partington (1998: 77) demonstrated that the word impressive in English does not have the same semantic prosody as impressionante in Italian and underlined the importance of such findings for research in translation studies. This has not been widely examined until now, although translation seems to be the ideal field to crosslinguistically analyse this phenomenon.

Semantic prosody is difficult for non-native speakers of a language to perceive, which is exactly what translators usually are. When translating from a second language into their mother tongue, missing semantic prosodies may lead to misunderstanding the intent of the source text, and mistranslating it in the target language. However, Stewart (2009) described an experiment in teaching semantic prosody to translators, in which he highlighted a number of problems for corpus users, teachers, 
learners, and translators. In his conclusion, he warned that they should not totally abandon intuition but should be aware that interpretation of corpus data is liable to subjectivity, and finally that they should not be put off by the apparently discouraging study of semantic prosody. The question of studying semantic prosody and integrating this information into a bilingual database is also an interesting challenge. We will address this in the ARTES Project (Kübler \& Pecman 2012), an online term and phraseological database which can be used as a writing aid for French speakers having to write scientific or technical papers in English, but also as a translation aid for specialised translation. Linguistic information on the collocational profile of terms or general scientific English words will be fully integrated in the database.

\section{The problem with collecting comparable corpora in different languages}

This study is intended to provide potential applications in specialised translation and specialised translation teaching. A parallel corpus consisting of source texts aligned with their translation in the target language could seem ideal for this objective. However, two major drawbacks prevented us from using such a corpus. A practical problem is that parallel LSP corpora are sparse, especially in scientific domains due to the position of English as a lingua franca in the scientific world. The second, more theoretical difficulty, lies in the specific characteristics of translated text (the translationese phenomenon described by Baker 1996), namely that translated texts are influenced both by the source language and by the translation process, and do not completely reflect the productivity of the target language. Therefore, comparable corpora seemed to be more appropriate to our objective. A comparable corpus can be defined as a collection of pieces of language assembled according to the same specific criteria in two languages (or in two different variants of the same language) with no translated texts. Collecting a comparable corpus which perfectly matches this definition is however a challenge, as the problem lies in finding texts belonging to the same genre in the two languages, especially in science, and between English and another language.

Taking into account this limitation, we used two kinds of corpora in English and French: general corpora and specialised corpora. English corpus linguistics has been providing linguists with general corpora for a long time; we therefore used the BNC and the Corpus of Contemporary American English (Davies 2008; henceforth CoCA), both of which are available on Mark Davies' website (http://corpus.byu.edu/) along with corpus query tools that are sophisticated enough for our purposes. The reason why we used both is that the BNC stops in 1992, whereas CoCA contains texts until 2010. Although they represent two different varieties 
of English, they allowed us to ascertain that we had samples of completely contemporary English.

French corpus linguistics has not produced such an advanced interface as the BYU, nor any balanced corpora of general French. However, the Leipzig Corpus Français, developed at the University of Leipzig (http://wortschatz.uni-leipzig.de/ws fra/), provides users with a corpus of 700 million words collected from newspapers, websites and the French Wikipédia. It is unfortunately not possible to access concordances or collocations with mutual information as with the BYU interface, but it provides the most significant co-occurrences of a given token with examples. Another interesting French corpus used here is Les Voisins de Le Monde developed at the ERSS, University Toulouse Le Mirail (http://redac.univ-tlse2.fr/voisinsdelemonde/). It contains an annotated corpus consisting of ten years of the newspaper Le Monde (around ten million words) and allows users to look for collocations and neighbours of lemmas, sorting results by frequency or mutual information. Although journalistic French is not totally representative of general French, it is as close to general as need be and quite different from a specialised corpus in earth science. To obtain concordances, we also used a small corpus consisting of one year of Le Monde newspaper, available with a concordancer developed in-house (http://wall.eila.univparis-diderot.fr).

For the study of specialised English and French, we used the Earth Science Corpus (ESC) compiled at the University Paris Diderot ${ }^{2}$. The ESC is also questionable as a comparable corpus, since on the English side it contains only scientific articles from international journals, while on the French side it is more mixed, containing scientific articles, $\mathrm{PhDs}$ and teaching material. As most French-speaking researchers in earth science have to write in English, articles in French are sparse, so the corpus had to be completed by articles from the Bulletin de la Société Française de Géologie. This difference between French and English corpora of scientific articles is pervasive in science, and is the same for other languages, as pointed out by Swales(2004). It is also possible that this situation has an influence on the French of science, but not always. Despite the difficulties involved in compiling a French corpus composed of the same kind of texts as its English counterpart, we will show that it is still possible to obtain comparable results. Finally, and in order to make the two sub-corpora as comparable as possible, both the English and French corpora were downsized to around 8 million words and sampled to contain texts of the same size ${ }^{3}$.

In a recent article, Louw and Château (2010) questioned some of Hunston's (2007: 252) examples of cause extracted from New Scientist. They suggested that some of the examples might come from articles written by non-native speakers of English. This can explain why some uses of cause seem unnatural. We tried to overcome this difficulty by 
keeping the names and, more significantly, the affiliations of authors, assuming that, when there was a native speaker of English, or when the affiliation was from an institution of the inner circle of English-speaking countries, the language of the article was considered as native (Volanschi 2008). Some uses of cause in our examples may not seem completely acceptable to native speakers of English, although expert native speakers use them. Consequently, non-native experts in earth science also use them, mimicking native speakers. However, some uses made by non-native experts may be unacceptable because of the influence of the experts' mother tongue; we wanted to avoid this trap.

In order to check the pervasiveness of semantic prosody across various scientific domains, we also used an English corpus in biology (6 million words) and smaller comparable English/French corpora (between about 300,000 and 1 million words per language) in a wide variety of microdomains, such as energy harvesting, bio-oil, nanofood, fat replacers, computer security, and neuroscience.

\section{French and English items in general language}

\section{1. 'Commit': an English verb with negative semantic prosody}

As Berber Sardinha (2000) concluded for the comparison between English and Portuguese, semantic prosody across languages is unpredictable for near-synonyms. In this section, we will first test this conclusion for a verb in general English and its French equivalent, namely commit and commettre. The Collins English Dictionary (2010) gives the following definition for to commit (note that we are only interested in one meaning of the verb, namely meaning number six in the dictionary):

\section{commit / kəmIt/}

VERB, -mits, -mitting, -mitted (tr) 1. to hand over, as for safekeeping; charge; entrust to commit a child to the care of its aunt 2. commit to memory, to learn by heart; memorize 3 . to confine officially or take into custody, to commit someone to prison 4. (usually passive) to pledge or align (oneself), as to a particular cause, action, or attitude a committed radical 5. to order (forces) into action 6. to perform (a crime, error, etc); do; perpetrate

The verb commit has been described by Partington (1998) as having negative semantic prosody, as it appears very often with words meaning something which is not desirable. This is confirmed by our observations in both CoCA and the BNC, comparing the collocates of commit in the newspaper sections. The first twenty collocates sorted by mutual information in the newspaper section of CoCA are given in Figure 1. 
Figure 1: First twenty collocates of 'commit' in the newspaper section of CoCA

suicide, crimes, conspiring, heinous, adultery, conspiracy, perjury, unspeakable, horrendous, fouls, espionage, cyanide, piracy, atrocities, incest, juveniles, acts, sin, thou, fraud

These results show that not only those nouns that are part of the verb's direct object are imbued with a negative aura of meaning but also adjectives or nouns, heads of the subject.

The results of the same query sorted by frequency, after discarding all the items that were not nouns and lemmatising nouns yields the following result: suicide, crime, conspiracy, offence, murder, arson

The BNC gives almost similar answers to the same query: suicide, crime, act, arson, murder, rape

Browsing through numbers (singular or plural) and through the presence or absence of determiners before the head noun object of commit in the BNC for example shows that singular nouns without a determiner are very often used (Figure 2).

Figure 2: Singular noun objects of 'commit' without a determiner, sorted by frequency (newspaper section of the BNC)

\begin{tabular}{lr}
\hline commit suicide & 27 \\
committed suicide & 25 \\
commit murder & 5 \\
commit arson & 4 \\
committing forgery & 3 \\
committing crime & 3 \\
commits suicide & 2 \\
committing adultery & 2 \\
\hline
\end{tabular}

Commit is thus very often encountered with uncountable nouns having a negative connotation in expressions that can sometimes be replaced by a single verb (as in to commit murder = to murder), highlighting its function as a light verb (or support verb).

Figure 3 shows countable noun objects of commit, including crime, which is more often used as a countable noun than as ancountable noun. Whereas to commit suicide will be considered by a native speaker as a usual connotation, to commit crime may sound less natural than to commit crimes or to commit a crime.

Figure 3: Plural countable noun objects of 'commit' sorted by frequency (newspaper section of the BNC)

committed crimes 7

commit crimes 5

commit burglaries 2

commit offences 2 
These very simple analyses have allowed us to confirm on the one hand that commit has negative semantic prosody, and on the other hand, to observe some linguistic characteristics in the combination of commit and a noun object. With a view to translation or second-language writing, these characteristics should be integrated into the ARTES terminological and phraseological base.

\section{2. 'Commettre': The (approximate) French equivalent of 'commit'}

The translation for commit in the bilingual dictionary Le Robert \& Collins Super Senior (2008) is given here:

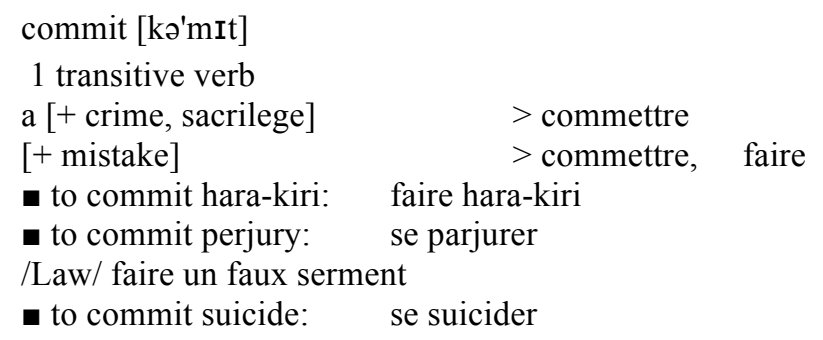

The dictionary does not give many examples, but some of them are significant for translators, and the most frequent expression using the verb, to commit suicide, is given an equivalent which is quite different from commettre. However, all the examples are built with objects having a negative connotation in English; the French equivalents of these transitive verb phrases also have a negative connotation. Some examples tell the reader that commit and its object can have different types of structures in French (e.g. to commit suicide $>$ se suicider).

Corpus consultation will confirm the hypothesis that the French equivalent of commit also has negative semantic prosody. The Leipzig Corpus Français was queried for the infinitive of the French verb commettre in the newspaper section only, following the same methodology as that used with the BNC and CoCA. The most significant cooccurrences of commettre are given in Figure 4 (sorted by frequency). This shows both left and right collocates, which explains the presence of words such as terroristes (potential subject of the verb) or $p u$ (modal pouvoir in front of the verb). A striking feature of commettre is that almost all of these lexical collocates have negative connotations, even though they are not head nouns of a potential object on the right of the verb.

Figure 4: Most frequent left and right collocates of 'commettre' in the Leipzig Corpus Français ${ }^{4}$

erreurs, erreur, attentats, actes, crime, crime, fautes, attentat, irréparable, terroristes, acte, ne, faute, infraction, complot, de, un, meurtre, pas, pu, vue, pour, à, qu, de, terroriste, délit, meurtres, atrocités, suicide, infractions, malfaiteurs, a, il, accusé, 
bogey $^{5}$, intention, délits, vol, police, commis, accusé, péché, conspiration, avoir, génocide, qui, coupable, méfaits, explosifs, criminelle, incitation, apprêtait, poussé, que, homme, forfait, bogueys, péchés, servi, empêcher, apprêtaient, avant, abus, criminels, sans, contre, attentat-suicide, directes, une, Al-Qaïda

Even more striking are the most frequent right lexical collocates of commettre (Figure 5). All these collocates, nouns or adjectives, have a negative connotation.

Figure 5: Most frequent right lexical collocates of 'commettre' in the Leipzig Corpus Français ${ }^{6}$

erreur, attentat, acte, faute, crime, terroriste, irréparable, complot, suicide, malfaiteurs, meurtre, conspiration, vol, infraction, atrocités, accusé, délit, criminelle, intention, explosifs, génocide, coupable, incitation, police, comploté, forfait, Al-Qaïda, incité

Looking for the most frequent collocates of the past participle commis gives the same results, with even more object nouns bearing a negative connotation. Here are some examples of sentences ${ }^{7}$ extracted from the Leipzig Corpus Français and containing either commettre or commis:

(1) Coin... a commis 31 fautes directes et elle n'a pu profiter de son service (Coin... committed 31 unforced errors and could not take advantage of her service)

(2) "La cour estime que la preuve établit sans doute que les deux suspects ont commis le crime de viol en réunion et meurtre", a déclaré le juge

T (...the two suspects committed the crime of gang rape...)

(3) Le nouveau vol a été commis entre $12 \mathrm{~h} 30$ et $20 \mathrm{~h} 30$, a indiqué la police cantonale.

(The new theft was committed...)

(4) Ils étaient aussi moins portés à consommer de la drogue, de l'alcool ou à commettre des crimes.

(...to consume drugs and alcohol and to commit crimes)

(5) Selon l'entourage de Vladimir Poutine, celui-ci aurait accusé la Géorgie de commettre un "génocide complet" en Ossétie du Sud

(... he is said to have accused Georgia of committing a "complete genocide"...)

(6) ... qui mangent du mouton le jour de l'aïd... sans pour autant se sentir coupable de commettre un péché

(who eat mutton on the day of the aïd without feeling guilty of committing a sin)

At first sight, it seems that commettre has the same semantic prosody as commit and combines with a roughly equivalent set of words having a negative connotation.

Les Voisins de Le Monde can help complete this analysis: although the web interface does not provide the user with concordances, it is possible to ask for the direct objects of the lemma commettre. Figure 6 gives the first 20 object cooccurences for the lemma commettre, sorted by mutual information.

Figure 6: First 20 cooccurrences of 'commettre' sorted by mutual information in Les Voisins de Le Monde

\begin{tabular}{llll} 
Lemma & Lemma $^{8}$ & Mutual & Frequency \\
\hline
\end{tabular}




\begin{tabular}{llll}
\hline & & information & \\
\hline commettre & même faute & 9.054 & 7 \\
commettre & erreur fatale & 9.054 & 11 \\
commettre & faute directe & 9.054 & 6 \\
commettre & erreur grave & 9.054 & 6 \\
commettre & acte illégal & 9.054 & 6 \\
commettre & nouvelle erreur & 9.054 & 5 \\
commettre & erreur historique & 9.054 & 6 \\
commettre & erreur de jugement & 9.054 & 6 \\
commettre & double faute & 9.054 & 10 \\
commettre & indélicatesse & 9.054 & 6 \\
commettre & grossière erreur & 9.054 & 7 \\
commettre & lourde erreur & 9.054 & 7 \\
commettre & erreur fondamentale & 9.054 & 6 \\
commettre & impair & 8.757 & 26 \\
commettre & bourde & 8.693 & 23 \\
commettre & déprédation & 8.674 & 13 \\
commettre & grosse erreur & 8.543 & 9 \\
commettre & grave erreur & 8.505 & 26 \\
commettre & larcin & 8.435 & 7 \\
commettre & lapsus & 8.361 & 14 \\
\hline
\end{tabular}

All these occurrences refer to something undesirable. The same results sorted by frequency yield the same type of undesirable objects (Figure 7).

Figure 7: Twenty most frequent occurrences of 'commettre' sorted by frequency in Les Voisins de Le Monde. The most frequent objects that collcate with commettre consist of nousn only, and not nouns modified by specific adjectives as is the case when arguments are sorted by MI.

\begin{tabular}{llll}
\hline Lemma & Lemma & $\begin{array}{l}\text { Mutual } \\
\text { information }\end{array}$ & Frequency \\
\hline commettre & crime & 6.721 & 1063 \\
commettre & erreur & 7.082 & 967 \\
commettre & attentat & 6.316 & 761 \\
commettre & acte & 5.825 & 450 \\
commettre & faute & 7.07 & 387 \\
commettre & atrocité & 8.271 & 334 \\
commettre & exaction & 7.879 & 320 \\
commettre & délit & 6.452 & 308 \\
commettre & meurtre & 5.982 & 235 \\
commettre & infraction & 6.583 & 207 \\
commettre & massacre & 5.862 & 202 \\
commettre & violence & 4.26 & 147 \\
commettre & violation & 6.172 & 138 \\
commettre & abus & 5.312 & 129 \\
commettre & fait & 3.91 & 125 \\
commettre & agression & 5.758 & 103 \\
commettre & assassinat & 5.008 & 101 \\
commettre & viol & 6.206 & 95 \\
commettre & irrégularité & 6.804 & 90 \\
commettre & vol & 4.671 & 89 \\
\hline & & &
\end{tabular}


These results are quite similar to the fuzzy results provided by the Leipzig Corpus Français . It is thus possible to conclude that commettre has the same negative semantic prosody as commit.

However, not all phrases in English have the same structure equivalent in French; the phraseological unit to commit suicide mentioned above does not have the same type of equivalent in French, where it is a single reflexive verb: se suicider. Another case is the phrase to commit adultery, which, as far as the data in the $\mathrm{BNC}$ and $\mathrm{CoCA}$ are concerned, cannot be used with a determiner, whereas it can be rendered in French either with the definite article le, or with the indefinite $u n$. Although commit and commettre have the same semantic prosody, their collocational profiles show differences which should be listed for translation.

Another issue with the contrastive analysis of commit and commettre is the possibility of irony noted by Louw (2000: 57):

\begin{abstract}
A secondary, although no less important attitudinal function of semantic prosodies is the creation of irony through the deliberate injection of a form which clashes with the prosody's consistent series of collocates.
\end{abstract}

Neither CoCA nor the BNC provides any examples of commit used with a word which does not have a negative connotation. On the other hand, the French commettre allows the cooccurrence with roman (novel) or oeuvre (d'art) (work (of art)), although neither roman nor oeuvre have a negative connotation. In such cases, the speaker (or writer) deliberately creates an ironic interpretation of the work or novel, implying that they are not very good. Even though it clashes with the usual series of collocates, the use of those two words is quite usual, almost lexicalised ${ }^{9}$. Relying on the same model of lexicalised irony, it is possible to say commettre une pièce de theatre ("commit a play"), but this would not be perceived as a normal collocation, as commettre un roman is ${ }^{10}$. However, we could not find any occurrences of commettre un roman in the Leipzig Corpus Français or in Les Voisins de Le Monde, or even in the $243,930,462$ words of the literary database Frantext ${ }^{11}$. A quick search on the Internet gave 676 results for commettre un roman and 29,400 results for commis un roman (committed a novel), whereas the same search for the trigram commit a novel revealed 203 occurrences, with quite a lot of noise, such as:

(7) These results demonstrate that activated TEC may commit a novel and previously unreported form of self-injury (fratricide)

(8) The minute you commit a novel to paper, take a photograph or build a website, you have essentially created a copyright for that work.

(9) If you commit a novel crime, the infraction may win months to reveal up and be reported nationally. 
Very few examples of commit a novel (verb + noun) can be found, but they still sound unidiomatic and possibly unclear to English native speakers. However, to perpetrate a novel/play/piece of writing would suggest irony in English (perpétrer un roman would sound unidiomatic in French). So though the two languages both use semantic prosody for irony, it doesn't necessarily concern the equivalent verb in the other language (which is consistent with the arbitrary character of collocational phenomena); it may be a semantically related but different verb that carries this connotation. This is a feature of interest to translators who would like to preserve the irony found in the French expression in the English target text..

\section{French and English items in earth science}

Taking into account the observations made by Louw and Château (2010), who found that semantic prosody tended to be smoothed in ESP, we tried to verify this assumption in the domain of earth science in English and French, and made a few tests in a variety of other domains. We started with the verb to cause and its French obvious translation causer. Then we moved on to a verb that has positive semantic prosody, to provide and its French frequently supposed equivalents.

\section{1. 'Cause' in earth science}

To cause has been described by Hunston (2007) as being possibly neutral in science, following analysis of a sample extracted from New Scientist. She thus concludes that "cause implies something undesirable only when human beings, or at least animate beings, are clearly involved" (Hunston 2007: 253). Louw and Château (2010: 759) however question this conclusion by giving results extracted from the science subcorpus of the BNC, which shows that the cooccurrences of cause with words that have a negative connotation are overwhelming and do not always imply animate beings. They also question the set of examples given by Hunston, suggesting that they may have been written by nonnative speakers of English (Louw \& Château 2010: 760), or that cause was used because there was no alternative possibility. They conclude from their analysis that, when the context of situation is incomplete, negative semantic prosody tends to be smoothed, and cause is used because it is difficult to replace by multi-word units such as bring about, which are perceived as verbiage in hard sciences.

We would like to examine the situation of cause in earth science and possibly enrich these hypotheses by the contrastive analysis between English cause and French causer ${ }^{12}$.

Many examples of cause with negative semantic prosody can be found in the 8 million word sub-corpus of earth science. The most frequent 
nouns which occur only to the right of the infinitive form cause are change (rank 26), damage (rank 29), failure and variations, among which only damage has a negative connotation, failure being a domainspecific term ${ }^{13}$, as shown in Figure 8. Apart from damage and problems, none of the nouns here have a negative connotation, which can lead to the assumption that cause does not always have negative semantic prosody in earth science, thus supporting Hunston's (2007) hypothesis.

Figure 8: Most frequent noun collocates for 'cause' in the English ESC

\begin{tabular}{lll}
\hline Rank & Frequency right & Collocate \\
\hline 26 & 10 & changes \\
29 & 10 & damage \\
30 & 7 & variations \\
31 & 9 & failure \\
32 & 4 & density \\
39 & 7 & melting \\
48 & 1 & waves \\
52 & 5 & problems \\
53 & 5 & pore \\
58 & 5 & ice \\
66 & 4 & track \\
78 & 2 & plumes \\
82 & 4 & inclinations \\
\hline
\end{tabular}

The examples of cause damage shown in Figure 9 match with the usual negative semantic prosody of the verb. Damage is caused, in which animate beings are involved.

Figure 9: Concordance of 'cause damage' in the English ESC cted blasts? (3) What dynamic processes cause damage? (4) What was sufficient dynamic pressure changes to cause damage. He postulated $\mathrm{s}$ them? Some landslides move slowly and cause damage gradually, $\mathrm{s}$ lower than cliff edge The waves that cause damage to the cliff in ircraft while in the atmosphere and can cause damage to structures, dges, canals and hydropower plants, and cause damage to hectares of $\mathrm{d}$ nificant process with high potential to cause damage in Bíldudalur. ntainous areas. Their high mobility can cause damage, not only inside njection of ash into the atmosphere can cause damage to aircraft or jor earthquake, the energy released can cause damage hundreds to thous

However, other examples show that, in agreement with Louw and Château's (2010) smoothing hypothesis, cause can be used in more neutral contexts; this is the case when the nouns collocating with the verb are domain-specific terms (Figure 10), or, if they are domainspecific terms, when they enter a specific colligation (cause something to do something):

Figure 10: Noun collocates to the right of 'cause' in the English ESC

causing local dilation

cause differences in the initial cone-derived mass flows

cause strong isotopic aging

causing a change in the brittle failure depth 
cause a pressure drop

causing abrupt solidification

causing subsidence, autobrecciation

causes a decrease in flow rate

cause pressure ridges

cause additional cooling

cause similar stress changes

cause considerable crystallization of olivine

cause a switch to explosivity

causes a high acceleration of the flow

cause caldera resurgence

causing heating, melting, groundwater release and outflow

caused flow

cause extensive channel overflows

causing a hydrostatic rebound

causing extensive flooding

causing inflation and slow spreading

causes this low resistivity of the dome

Although some terms are modified by adjectives which could be interpreted as having a negative connotation (e.g. low resistivity), none of those terms have a negative connotation, which is confirmed by the following longer extracts, chosen from articles written by researchers affiliated to an English-speaking institution:

(10) The presence of extensive cold-based glacial deposits (e.g., Head and Marchant, 2003), and the likelihood that circulation patterns in the past would continue to supply snow and ice to Tharsis (e.g., Forget et al., 2006), strengthens the probability that there was sufficient precipitation to cause melting and recharge during earlier periods of higher heat flux. ${ }^{14}$

(11) The alternative feedback occurs, when the rate of melting is either less than the rate of drainage or is negative due to the freezing-on of water to the ice base. This will cause an increase in till strength, which in turn will increase the shear heating within the sediment, leading to an increased melt rate. ${ }^{15}$

The verb can also enter a passive construction in which the patients are often designated by domain-specific terms, as in Figure 11. 
Figure 11: Grammatical subjects of passive constructions of the verb

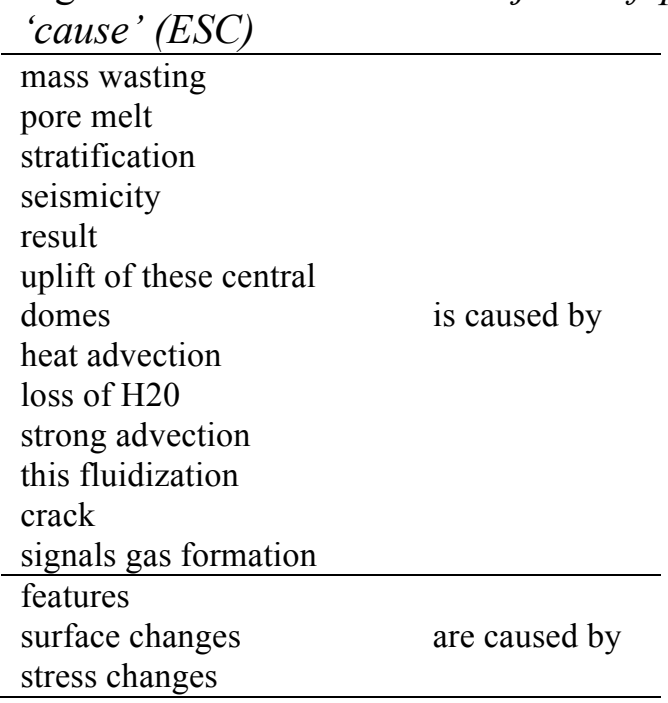

Finally, the colligation cause something to VERB also yields examples in which there is no semantic prosody:

(12) When a particle impacts the sensing plate, the film deforms, causing an electric charge to be generated.

(13) it is likely that the source was spatially distributed, i.e., that a small rock fall triggered landsliding downslope, causing the flow to bulk up gradually within the proximal source region.

The conclusion that can be drawn from these results is that both the Hunston (2007) and the Louw and Château (2010) hypotheses have been confirmed: the verb cause does have negative semantic prosody when animate beings are involved. Another way of saying this would be to state that, when the verb is used with object arguments that are domainspecific terms, there is no semantic prosody. So, the verb does not overwhelmingly present negative prosody in earth science. However, as cause usually has negative semantic prosody in general language, a neutral use can sometimes be perceived as unusual, even for a native speaker if they are not an expert in the field. This is first only the case in the colligation cause NOUN (or caused in a passive construction whose colligation is NOUN (was) caused), i.e. the colligation cause something to $V E R B$ does not have negative semantic prosody, nor does it sound unusual when used with a domain-specific term. Second, coming back to Louw's (1993: 157) definition of semantic prosody (i.e. "a consistent aura of meaning with which a form is imbued by its collocates"), and to the pervasiveness with which it is characterised, it is possible to say that there is a gradation in the acceptability of a cooccurrence, which is influenced by the use of the verb in general language.

Examples (14) and (15) below show that words that have a negative connotation in general language, can become neutral domain-specific terms and keep a neutral company with the verb. Although the use of 
cause is neutralised in examples (14) to (17), (14) and (15) seem more natural because the patient function (i.e. what is caused) is filled by earthquake and eruptions, both of which terms are neutral here; however, when used in general language, they usually occur in contexts where they represent something undesirable for human beings. In examples (16) and (17), however, the things that are caused are obviously terms which are not common in general language, i.e. heat advection and mud volcanoes (and not volcanoes alone).

(14) Moreover, considering that tectonic earthquakes are caused by the slip of two lithospheric blocks along a fault.

(15) intermittent eruptions are caused by intermittent magma supplies with large supply volumes

(16) Many thermal springs reflect heat advection caused by rapid fluid even from a "normal" geothermal gradient.

(17) Mud volcanoes are commonly observed in accretionary and caused by dewatering and excess fluid pressure in actively deforming, young, high porosity sediments

\subsection{The French verb 'causer' in earth science}

Causer is the French equivalent of to cause and has the same semantic prosody. In general French, it has a very clear negative semantic prosody, which is proven for example by looking up its most frequent collocates in the Leipzig Corpus Français (Figure 12) and in Les Voisins de LelMonde (Figure 13).

Figure 12: Most frequent collocates of 'causer' in the Leipzig Corpus Français

dommages, peut, dégâts, peuvent, pourrait, problèmes, des, tort, graves, pu, pouvant, préjudice, ennuis, pourraient, blessures, maux, perte, que, mort, qui, surprise, dommage, soucis, importants, risque, sans, Fugace, susceptibles, troubles, ou, ne, pertes, virus, sérieux, CEST, aux, désagréments, irréversibles, préjudices, cancer, inondations, lésions, provoquer, failli, dégâts, maladies, de, va, qu, maladie, pas, aurait, irréparables, , , vents, surprises, torts, accidents, Maloq, lui, irritations, tracas, ravages, douleur, brûlures susceptible, gêne, si, respiratoires, infections, cancers, accident, allait, chez, bien, Abdulla, CET, pouvaient, problème

Apart from a few exceptions, such a proper nouns or acronyms (Maloq, Abdulla, CET), some verbs (provoquer, faille, allait, pouvait), and a few others, the vast majority of the collocates, be they nouns (dommages, dégâts, problèmes, prejudice, blessures, maux, pertes, etc.) or adjectives (graves, irréparables), subject or object of the verb, have a negative connotation. Some intensifying adjectives, such as important, are often used with words having a connotation in order to sustain or accentuate the connotation.

The interface for Les Voisins de Le Monde yields the same results for the right collocates of the verb (object position), as shown in Figure 16. 
Figure 13: Right collocates of 'causer' sorted by mutual information (Les Voisins de Le Monde)

dommage irréversible, dégât irréparable, dommage irréparable, dégats, tracas, important dégât, frayeur, dégât matériel, dégât, tort, ravage, dommage, désagrément, préjudice, traumatisme, gêne, émoi, perturbation, déception, ennui, embarras, lésion, remous, trouble, embouteillage, désastre, nuisance, chagrin, souffrance, malheur, déboire, souci, blessure, perte, infection, trou, choc, désordre, décès, mort, pollution, plaie, Sorbonne, destruction, inondation, scandale, douleur, émotion, mal, ruine, incendie, fracture, accident, cancer, pénurie, université, surprise, chute, inquiétude, disparition, bruit, maladie, catastrophe, préoccupation, maximum, danger, malaise, peur, retard, commune, drame, problème, difficulté, tension, victime, effet, risque, crise, million

Apart from some noise (Sorbonne, université) and some words which do not have a negative connotation (million, effet, and maybe surprise), all the other collocates have a negative connotation.

In the French ESC, the first noun collocate for causer is dégâts (rank 10), then dommages (rank 15), then the axiomatic adjective importants (rank 21, modifying dégats or dommages); the first domain-specific term to appear is erosion (rank 25). Figure 14 shows the nouns appearing as direct objects of the verb among its first 80 collocates.

Figure 14: Nouns in the first 80 collocates of 'causer' (French ESC)

\begin{tabular}{ccll}
\hline Rank & Frequency & \\
\hline 11 & 10 & dégâts \\
15 & 8 & dommages \\
25 & 4 & érosion \\
32 & 1 & ruptures \\
33 & 2 & roches \\
34 & 1 & refroidissement \\
37 & 3 & effondrement \\
40 & 2 & avalanches \\
41 & 2 & éruptions \\
45 & 2 & victimes \\
47 & 2 & tsunamis \\
71 & 2 & dossier \\
74 & 2 & batiments \\
75 & 1 & brûlures \\
78 & 2 & aspérités \\
80 & 2 & altérations \\
\hline
\end{tabular}

Compared with the first noun collocates of to cause in English, the French verb strikingly shows many more collocates having a negative connotation; this difference may be partly due to the fact that the French corpus is not as homogeneous and contains some popularisation websites, so is less specialised and closer to general language.

However, this difference presents the advantage of providing a great variety of examples in a specialised domain, giving rise to two major observations. 
Firstly, following Hunston (2007), we noted that causer had a clear negative semantic prosody when expressing undesirable effects for human beings as shown by the following examples:

(18) parce qu'elles sont la cause des dommages causés aux différentes constructions suite à un séisme

(because they are the cause of the damage caused to various constructions after a seismic event)

(19) peuvent éliminer les pertes de vie et les dommages causés aux propriétés par les avalanches de pierres

(can eliminate the loss of life and damage caused to properties by rock avalanches)

(20) Elles ont causé d'importants dégats sur l'île de Kauaì

(They caused substantial damage on the island of Kauai)

(21) l'éruption de 1996 ayant causé de nombreux dégats sur les infrastructures routières

(the 1996 eruption having caused damage in many places to the road infrastructures)

(22) l'éruption de 1768 du volcan Cotopaxi n'a pas causé de victimes car la population...

(the 1768 eruption of the Coropaxi volcano did not cause any casualties, because the population...)

The most frequent nouns used in this case are dommages, dégats, pertes, victimes, désastres, destruction, mort, etc., all describing something undesirable for human beings.

Secondly, when used with domain-specific terms, causer did not present negative semantic prosody, following Hunston's (2007) observations, but also Louw and Château's (2010) conclusion that negative semantic prosodies can be smoothed in science.

(23) Le soulèvement du panache peut également causer l'amincissement et l'extension de la lithosphère (...can also cause thinning and extension of the lithosphere)

(24) Le déplacement le long des décrochements peut causer la rotation des blocs rigides autour d'axes verticaux

(...can cause the rotation of rigid blocs around vertical axes)

(25) déshydrate et hydrate le manteau sous-jacent pour causer une fusion partielle de la croûte par diminution

(...to cause partial fusion of the crust)

(26) La forte altération des roches a causé la remobilisation des éléments incompatibles (...caused the remobilisation of incompatible elements)

(27) est négligeable dans le cas d'une anisotropie causée par du cisaillement pur (...in the case of anisotropy caused by pure shear)

These examples and all the other occurrences in the corpus show that in science, something causes a scientific phenomenon which could have undesirable effects on human beings; however, this consequence is usually not mentioned, nor taken into account in the description of the phenomenon and its consequences. Even words which could have a negative connotation are used neutrally, including perturbations, séisme, éruption, sous-évaluation, etc. Although these examples could sound 
odd to native speakers of French, they are currently used by French scientists, which is in line with what Hunston (2007) has observed. Furthermore, we cannot follow Louw and Château (2010) in saying that French uses causer because there is no other possible word in scientific French, which is what they suggested for the English cause. Nearsynonyms, such as provoquer, engendrer, entraîner, produire, faire naître could also have been used.

As international research in earth science is mainly published in English, it could be possible that the French use of causer is influenced by the English use of cause. However, the number of occurrences found in the French corpus does not allow us to confirm this hypothesis.

In order to verify that the neutral use of causer was widely distributed throughout sciences in general, we looked for occurrences in smaller corpora in a wide variety of domains. Here are some examples which demonstrate that the negative semantic prosody of causer tends to be smoothed in scientific domains:

(28) augmentation de l'adsorption... Cette augmentation peut être causée par une élévation des interactions polymère-surface (Nanofood corpus) (this increase can be caused)

(29) on élimine les artefacts électriques causés par les mouvements oculaires et musculaires à l'aide de techniques telles que l'Analyse en Composantes Indépendantes (Brain Computer corpus) (electrical artefacts caused by)

(30) Cerveau et cognition : si proches... et si lointains 2.1. Comment la cognition est-elle causée par le cerveau (Neuroscience corpus)

(How is cognition caused by the brain?)

(31) les vibrations hautes-fréquences causées par un impact permettent par leur perception à travers la main, de différencier différent matériaux entre bois et métal (Robot hand corpus)

(high-frequency vibrations caused by)

(32) Ainsi, le vivant est causé par le non vivant et se matérialise dans du non vivant (des atomes et molécules) (Synthetic biology corpus)

(the living is caused by the non-living)

If semantic prosody tends to be smoothed in science, the same observations should be made for verbs belonging to the same semantic class as to cause and causer, i.e. which share the same semantic preference, and sometimes the same semantic prosody. This will be dealt with in the next section.

\subsection{Equivalents in earth science}

In the English ESC, we looked for the following near-synonyms: engender, generate, give rise to, induce, lead to, produce, result in. A few of them are used with general scientific language terms, such as problems, issues, results, precision, etc. All of them however are mostly used with domain-specific terms. 
- engender: This verb usually collocates with a domain-specific term, such as a rapid inflation, spatial changes of density, thaw drainage, magmatic pulses, etc. Only a few occurrences show negative semantic prosody, when the verb collocates with a term from general scientific language (GSL); as only a few occurrences with GSL terms are neutral and some others are positive, it is not possible to say anything about the general tendency as far as semantic prosody is concerned.

- generate: All the occurrences of generate have collocates which refer to a domain-specific term: an across track swath, the bedforms, tsunamigenic landslide, sediment-rich floors, large viscous flows, etc.

- give rise to: this verb presents a few collocates belonging to GSL and which have negative semantic prosody: errors, phase errors, a rather confusing situation. All the other collocates are neutral and either belong to GSL (differences, the observed distribution, a positive feedback, the possibility, the question, a debate, a process), or are domain-specific terms (a normal tectonic earthquake, shallow angles, black lower unit, thick dust, VLP, large tidal currents, various eruptive episodes, young monogenetic flows, crack interactions, strong backscatter, weak backscatter, conductive wings, magmatic segments).

- induce: the vast majority of this verb's collocates belongs to domainspecific terms (failure, earthquakes, the observed seismicity, collapse, crystallisation, slip, strain, an eruption, erosion, fracture, landsliding, significant melting).

- lead to: collocates for this verb mostly belong to domain-specific terms describing various phenomena, and it could be replaced by cause (an eruption, brittle shear, rupture, failure, a transition, an averaged $3 D$ rate, deformation, liquefaction, rockfalls, depressurization, transient segregations, deeper crevasses, distortions, exorbitantly high stress, flow acceleration, increased flow, intensified melting, pulsatory behaviour, total deglaciation, a potential lahar, calving). A few terms belonging to GSL can also be found: more realistic estimates, improved estimates, the definition, the proposal, an interpretation, the following solution, a better understanding, the conclusion, the suggestion.

- produce: this verb is used neutrally either with domain-specific terms (waveforms, large forces, a force, a nonzero CLVD component, glacial earthquakes, the Farallon Island velocity, synthetics with considerable mismatch, high levels of seismicity, a lava dome, a mean signal-to-noise ratio, a plume) or GSL terms (probabilistic outputs based on ensemble models, simulated outputs which compare in detail, this result).

- result in: this verb massively collocates with domain-specific terms describing phenomena: an eruption, consistent plume anomalies, a maximum deviation of the CMP location, the formation, unstable 
slip, lower basal roughness, the formation of shear fractures, a crack.

The verb to provide described by Stubbs (1995: 247-248) as bearing positive semantic prosody, and which is semantically related to the above-mentioned verbs, presents the interesting feature of keeping its positive semantic prosody in earth science. In general English, it is often found in the company of words like care, food, help, jobs, relief and support, which describe something desirable for human beings. This is also the case in earth science, although not always with nouns, but also with noun modifiers (nouns or adjectives) which have a positive connotation and give a positive evaluation to the noun used: an accurate base map, position accuracies, information, support for the type of model advocated by, important palaeo-environmental proxies, a complete conceptual model, sufficient strength, the most realistic analogue, state of the art tsunami sources, plausible explanation.

Although in these cases, the verb and its collocates represent something that is evaluated as desirable by researchers, domain-specific terms are also used and, in that case, contribute to the smoothing of semantic prosody: provides the stress, providing the fractures, provide magma to overlying volcanic fissures, providing a deformable water-filled layer.

The same types of observations can be made for the French verbs which are near-synonyms of the verb causer: engendrer, faire naître, provoquer, produire, occasionner, susciter, amener, apporter, fournir. However, there is no univocal matching between English and French equivalents and their use in LSP and GSL. Some French verbs develop specialised uses, while others only have GSL uses. While apporter only has neutral GSL language uses (Figure 15), susciter also presents massively GSL uses, out of which a slight tendency to negative semantic prosody can be observed (Figure 16).

Figure 15: Objects of 'apporter' in the French ESC: General Scientific French

réponses, informations, bénéfice, précisions, vision globale, point de vue, solutions, arguments, indications, la preuve (supplémentaire), une protection, ses compétences, résultats complémentaires, explication plausible, meilleure maîtrise, contribution, soutien, amélioration, méthode, données, éléments intéressants, indications, connaissances, outil, la démonstration, renseignements, explications, éclairage quantitatif, un regard nouveau, un atout, son concours

Figure 16: Objects of 'susciter' in the French ESC

\begin{tabular}{ll}
\hline \multirow{2}{*}{ positive GSL } & $\begin{array}{l}\text { des recherches novatrices, des développements importants, un } \\
\text { intérêt tout particulier / un grand intérêt, beaucoup de curiosité, un } \\
\text { ensemble de réponses, l'espoir, un attrait marqué }\end{array}$ \\
\hline negative GSL & $\begin{array}{l}\text { grandes déstabilisations, controverses (de nombreuses } \\
\text { controverses), critiques (de nombreuses critiques), la plus grande } \\
\text { confusion, plusieurs interrogations, la colère, des problèmes, des } \\
\text { discussions interminables, une certaine incompréhension, le }\end{array}$ \\
\hline
\end{tabular}


scepticisme, l'opposition, l'opposition virulente, des protestations,

de nombreuses craintes, la plus grande inquiétude, une rupture

brusque

neutral LSP des réajustements isostatiques, des écoulements, un débordement

The opposite is also possible; occasionner is massively used with domain-specific terms in the direct object position, as shown in Figure 17.

Figure 17: Domain-specific term objects (LSP) and general scientific language term objects of 'occasionner' in the ESC:

\begin{tabular}{ll}
\hline & $\begin{array}{l}\text { régénérescences ponctuelles, des ruptures } \\
\text { de pente, coulées boueuses, replats, des } \\
\text { calderas, une pente, des fronts de } \\
\text { concentration abrupts, surélévation, dépôt } \\
\text { de cendres, l'engravement des terrains, } \\
\text { une focalisation des ondes, un transport } \\
\text { de fluides, une mise en charge gravitaire, } \\
\text { bombement en surface, des houles, un } \\
\text { plissement, chutes de cendres, des lahars, } \\
\text { un volcanisme exceptionnel, une fonte } \\
\text { intensive du manteau neigeux }\end{array}$ \\
\hline degâts, victimes, perturbations, risque \\
potentiel, préjudices, perte de vies \\
humaines, dommages, destructions, \\
pertes humaines, d'importantes dépenses
\end{tabular}

In most cases, there is no semantic prosody, except when used in contexts where human beings are directly concerned (pertes de vies humaines, victimes). Some specialised uses remain neutral, even though they could be analysed as presenting negative semantic prosody because of the potential negative connotation of their direct objects, as in occasionner des pertes de matière, une surcharge, une érosion. Here, perte, surcharge, and érosion are only neutral descriptions of a phenomenon and do not concern human beings.

Along the same lines as the English verb provide, the French equivalent fournir does have positive semantic prosody in general language, and has a tendency to remain positive in the domain of earth science. Objects of the verb are often GSL nouns modified by an adjective with a positive connotation, such as un outil prometteur (a promising tool), des informations précieuses (valuable information), un critère de correlation fiable (a reliable correlation criterion), des résultats satisfaisants (satisfying results), une explication plausible (a plausible explanation), etc.

The conclusion that can be drawn from the observations on cause and other verbs (in English or in French) should take into account the domain in which the verbs are used and the type of collocates. When human beings, researchers included, are concerned with something desirable (such as a complete model) or undesirable (such as a 
landslide), the verbs bear positive or negative semantic prosody. In the case of researchers, things that are provided for example are evaluated as positive for science, in which case intensive or evaluative modifiers can be found. On the other hand, when the same verbs are used in the specific domain, even though they bear this aura of positive or negative meaning, semantic prosodies are smoothed. When semantic prosodies are smoothed, near-synonyms can be interchangeable, as they do not bear any negative or positive aura of meaning, as shown in the following French extract, in which causer could be replaced with engendrer, générer, provoquer, etc:

(33) ils [les mouvements du noyau] créent le champ magnétique qui nous protège du vent solaire, il n'est pas impossible qu'ils déclenchent des instabilités dans le manteau et causent la naissance de points chauds ; ils perturbent la rotation de la Terre et sans doute, en conséquence, le régime de la circulation atmosphérique. (they [the core movements] create the magnetic fields which protects us from solar winds, they may trigger intabilities in the mantle and cuse hotspots ; the perturbate the Earth's rotation and probably therefore, atmospheric circulation regime)

Here déclencher des instabilités, causent and perturbent usually refer to something undesirable when human beings are concerned. Other elements of negative semantic prosody co-oocur with the verb causerwithout necessarily having a syntactic relationship (instabilités, perturbent). Thus la Terre (the Earth) is considered as a metaphor of an animate being which can present instability, to which undesirable things can be caused and which can be perturbed. However, this is a neutral description of what happens to the Earth. The presence of other negative elements is also smoothed by the fact that they are used in a specific scientific domain.

\section{What about semantic prosody in the translation process?}

Although semantic prosody is generally likely to be smoothed in the translation process and as a result some verbs can be interchangeable, it still remains important to detect the presence or absence of the phenomenon, in order to correctly translate this presence or absence. Here are some examples extracted from texts in the ESC. Some texts have been translated by students and corrected by their translation trainers:

(34) The shape of the coarser debris surges is controlled by their heterogeneity, which causes a higher crest than in a homogeneous flowing mass (Figure 18). La forme d'une coulée épaisse dépend de l'hétérogénéité des matériaux qu'elle transporte. La crête de la vague est ainsi plus haute que celle d'une coulée homogène (illustration 18).

(35) A driving moment is the moment of the forces trying to cause a failure. Le moment moteur est le moment où les forces tendent à provoquer un glissement de terrain. 
(36) Intense slope erosion causes input of fine material into the channel that forms a slurry; if the slurry is dense enough, surges are formed with accumulation of boulders at the front, forming a temporary dam; the slurry overtops this dam or causes it to slide into motion.

Une pente très érodée alimente le chenal en matériaux fins, ce qui crée de la boue liquide. Si cette boue est suffisamment dense, les coulées se forment par accumulation de blocs à l'avant et constituent un barrage momentané. La boue recouvre ce barrage ou déclenche un glissement.

(37) As this westward drift is mainly caused by motion of the Pacific plate, it does not imply westward motion of other plates, such as the African plate.

Comme cette dérive vers l'ouest s'explique principalement par le mouvement de la plaque pacifique, elle n'implique pas le déplacement vers l'ouest d'autres plaques, comme la plaque africaine.

(38) These plumes appear to be "anchored" to the dense layer, but they state that any motions imposed upon the dense layer may cause lateral motion of the "anchor points" at which the plumes are fixed.

Ces panaches semblent être « ancrés » à la couche dense, mais leur présence démontre que tout mouvement imposé à la couche dense peut générer des mouvements latéraux chez les «points d'ancrage » auxquels les panaches sont fixés.

(39) ...thermal conditions necessary to cause melting at the base of a snowpack ...les conditions thermiques nécessaires pour provoquer la fonte à la base de la couverture de neige.

Translation strategies in examples (34) to (39) are quite varied and show that cause does not present a specific semantic prosody that should be rendered in the translation process. This may be another demonstration that semantic prosody can be smoothed in scientific contexts. Choosing not to translate cause by causer or one of its near-synonyms in French raises another issue for translators. As causer in general language is perceived as having negative semantic prosody, translators (who are not experts in earth science) reject the use of causer (as native experts would use it in French), because their perception of causer in earth science is contaminated by their knowledge of causer in general language. So the question is whether translators should follow their norm, based on general language, over the norm of native experts in the domain.

However, contexts in which semantic prosody does exist must be translated with the correct semantic prosody in the target language:

(40) While the Unzen eruptions have caused deaths and considerable local damage, the impact of the June 1991 eruption of Mount Pinatubo was global.

Les éruptions du volcan Unzen avaient causé des morts et de considérables dommages, mais seulement au niveau local. Au contraire, l'éruption du Mont Pinatubo en juin 1991 a eu des effets sur l'ensemble de la planète.

It could be useful to provide translators with a terminological and phraseological database including information about semantic prosody and equivalents in target languages, in order for them to decide which norm they will apply. This is what we intend to do in the ARTES database (Pecman et al. 2010; Kübler \& Pecman 2012). 


\section{Conclusion}

We have shown that semantic prosody can be found in scientific texts according to the context in which verbs presenting this phenomenon were used. We have confirmed Hunston's (2007) finding that semantic prosody is linked to effects on human beings - also the case in scientific texts. The use of corpus data has allowed us to demonstrate, against intuitive reasoning, that the negative semantic prosody of verbs in general language was smoothed in LSPs. The pervasiveness of semantic prosody makes it difficult even for a native speaker to rely on intuition to judge the acceptability of specialised uses of verbs such as cause or causer.

Semantic prosody in English verbs can also be found in their French equivalents. However, although native French experts in earth science use verbs such as causer and fournir in the same neutral environment, translators seem to have strategies that avoid using verbs that have a strong semantic prosody in a neutral setting. This is coherent with the normalisation principle that translators apply to their translations. It could then be interesting to use corpus linguistics results to augment the ARTES terminological and phraseological database in items presenting semantic prosodies in English and linking them to their equivalents in French. This could lead to a better use of specialised items in the translation process.

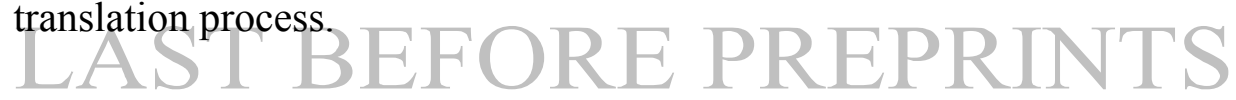

Notes

${ }^{1}$ Although in his 1993 article Louw attributed the paternity of the term to John Sinclair in a personal communication dating from 1988 (Louw 1993: 158).

2 This corpus was compiled by MA students and cleaned by us.

${ }^{3}$ The French corpus contains 16.5 million words, and its English counterpart 17 million words.

${ }^{4}$ Leipzig Corpus Français, accessed 12/03/11.

${ }^{5}$ Bogey is a term belonging to the specialised domain of golf and appears in sentences such as: Mais il a commis des bogueys de trois coups roulés lors de trois trous consécutifs. A bogey is a type of counter-performance in golf, i.e. something undesirable.

${ }^{6}$ Leipzig Corpus Français, accessed 14/03/11.

${ }^{7}$ Litteral translations are given her, in order to help readers who do not understand French; those are not attested translations

${ }^{8}$ All the arguments of the verb have been lemmatised, which explains why the is no agreement between nousn and adjctives in the french objects of commettre

${ }^{9}$ This process remains productive in French, however, as shown in this example from a satirical French newspaper, in an article imagining the confessions of the various members of the French government who had taken advantage of their position to take planes for their private use and let the state pay: "Bonjour, je m'appelle Alain. En mars 2010, secrétaire d'état à la Coopération, j'ai commis un aller-retour en Martinique dans un avion privé." (Le Canard Enchaîné, 09/02/11). ("I committed a round trip.")

${ }^{10}$ It seems however that the perception of commettre un roman depends on different factors, such as age for example. Not all French native speakers perceive this expression as being ironical and demeaning for the quality of the novel (roman).

${ }^{11} \mathrm{http}: / / w w w . f r a n t e x t . f r$, accessed 24/01/11. 


\footnotetext{
${ }^{12}$ Some polysemy is involved with causer in French, as the verb also means to chat, although this meaning will not be taken into account here: as it belongs to an informal register, it is almost impossible to find it in scientific texts, which generally belong to a genre that has a more formal register.

${ }^{13}$ A failure is a landslide involving a downward and usually sudden and rapid movement of newly detached segments of bedrock sliding or slipping over an inclined surface of weakness, as a surface of bedding, jointing or faulting, or some other preexisting structural feature (source: http://www.granddictionnaire.com, accessed 10/10/10).

${ }^{14}$ Russell, P.S. \& Head, J.W. 2007. The Martian hydrologic system: Multiple recharge centers at large volcanic provinces and the contribution of snowmelt to outflow channel activity. Planetary and Space Science 55: 315-332.

${ }^{15}$ Bennett, M.R. 2003. Ice streams as the arteries of an ice sheet: their mechanics, stability and significance. Earth Science Reviews 61, pp. 309-339
}

\section{References}

Baker, M. 1996. Corpus-based translation studies: The challenges that lie ahead. In Terminology, LSP and Translation: Studies in language engineering. In honour of Juan C. Sager, H. Somers (ed.), 175-186. Amsterdam / Philadelphia: John Benjamins.

Berber Sardinha, T. 2000. Semantic prosodies in English and Portuguese: A contrastive study. Cuadernos de Filologia Inglesa 9(1): 93-110.

Bowker, L. 2007. De la lexicologie à la terminologie: Etude de la prosodie sémantique à l'aide de corpus. In Lexicographie et Terminologie: Compatibilité des modèles et des méthodes, M-C. L'Homme \& S. Vandaele (eds), 189-217. Ottawa: Presses de l'Université d'Ottawa.

Collins English Dictionary, 2010. [Collins $30^{\text {th }}$ anniversary edition of $10^{\text {th }}$ revised.] London / Glasgow: Collins

Curado Fuentes, A. 2001. Lexical behavior in academic and technical corpora: Implications for ESP development. Language Learning \& Technology 5(3): 106-129.

Davies, M. (2004-) BYU-BNC: The British National Corpus. http://corpus.byu.edu/bnc, accessed 23/01/11.

Davies, M. (2008-) The Corpus of Contemporary American English (CoCA): 410+ million words, 1990-present. http://www.americancorpus.org, accessed 23/01/11.

Frantext: ATILF, CNRS / Nancy-Université. http://www.frantext.fr/, accessed 24/01/11.

Hood, S. 2006. The persuasive power of prosodies: Radiating values in academic writing. Journal of English for Academic Purposes 5: $37-$ 49.

Hunston, S. 2002. Corpora in Applied Linguistics. Cambridge: Cambridge University Press.

Hunston, S. 2007. Semantic prosody revisited. International Journal of Corpus Linguistics 12(2): 249-268.

Kübler, N., Bordet, G. \& Pecman M. 2010. La linguistique de corpus entretient-elle d'étroites relations avec la traduction pragmatique? In Passeurs de Mots, Passeurs d'Espoir: Lexicologie, terminologie et traduction face au défi de la diversité, M. Van Campenhoud, T. Lino \& R. Costa (eds), XX-XX. Paris: AUF. 
Kübler, N. \& Pecman, M. 2012. Providing information on semantic prosody and preference in an online LSP dictionary. In Electronic Lexicography, S. Granger \& M. Paquot (eds). Amsterdam: John Benjamins. 187-209

Leipzig Corpus Français: Leipzig University: http://wortschatz.unileipzig.de/ws fra/, accessed 24/01/11.

Les Voisins de Le Monde, CLLE/ERSS, Université de Toulouse II Le Mirail: http://redac.univ-tlse2.fr/voisinsdelemonde/, accessed 24/01/11.

Louw, B. 1993. Irony in the text or insincerity in the writer? The diagnostic potential of semantic prosodies. In Text and Technology: In honour of John Sinclair, M. Baker, G. Francis \& E. TogniniBonelli (eds), 157-176. Amsterdam: John Benjamins.

Louw, B. 2000. Contextual prosodic theory: Bringing semantic prosodies to life. In Words in Context: In honour of John Sinclair, C. Heffer \& H. Saunston (eds), 48-94. Birmingham: ELR.

Louw, B. \& Château, C. 2010 . Semantic prosody for the $21^{\text {st }}$ century: Are prosodies smoothed in academic context? A contextual prosodic theoretical perspective. In Statistical Analysis of Textual Data: Proceedings of the tenth JADT Conference, S. Bolasco, I. Chiari \& L. Giuliano (eds), p. 754-764. http://lexicometrica.univparis3.fr/jadt/jadt2010/tocJADT2010.htm, accessed 07/03/11.

Nelson, M. 2006. Semantic associations in business English: A corpusbased analysis. English for Specific Purposes 25: 217-234.

Newmark, P. 1988. Pragmatic translation and literalism. TTR: Traduction, Terminologie, Rédaction 1(2): 133-145.

Partington, A. 1998. Patterns and Meanings: Using corpora for English

$T$ language research and teaching. Philadelphia PA: John Benjamins.

Partington, A. 2004. "Utterly content in each other's company": Semantic prosody and semantic preference. International Journal of Corpus Linguistics 9(1): 131-156.

Pecman, M. 2007. Approche onomasiologique de la langue scientifique générale. Revue Française de Linguistique Appliquée: Lexique des écrits scientifiques 12(2): 79-96.

Pecman, M., Juilliard, C., Kübler, N. \& Volanschi, A. 2010. Processing collocations in a terminological database based on a crossdisciplinary study of scientific texts. In Cahiers $d u$ Cental: eLexicography in the $21^{\text {st }}$ Century: New challenges, new applications, S. Granger \& M. Paquot (eds). 249-262

Le Robert \& Collins Super Senior. 2008. London / Glasgow: HarperCollins; Paris: Le Robert.

Sinclair, J. 1987. Looking Up: An account of the COBUILD project in lexical computing and the development of the Collins COBUILD English language dictionary. London / Glasgow: Collins.

Sinclair, J. 1991. Corpus, Concordance, Collocation. Oxford: Oxford University Press.

Sinclair, J. 1996. The search for units of meaning. Textus 9: 75-106.

Stewart, D. 2009. Safeguarding the lexicogrammatical environment: Translating semantic prosody. In Corpus Use and Translating: Corpus Use for Learning to Translate and Learning Corpus Use to Translate, A. Beeby, P. Rodriguez-Ines \& P. Sanchez-Gijon (eds), 29-46. Amsterdam: John Benjamins.

Stewart, D. 2010. Semantic Prosody: A critical evaluation. New York / London: Routledge. 
Stubbs, M. 1995. Collocations and semantic profiles. On the cause of the trouble with quantitative studies. Functions of Language 2(1): 23-55.

Stubbs, M. 2001. Words and Phrases: Corpus studies of lexical semantics. New York: Blackwell.

Swales 2004

Tognini-Bonelli, E. 2001. Corpus Linguistics at Work. Amsterdam: John Benjamins.

Tribble, C. 2000. Genres, keywords, teaching: Towards a pedagogic account of the language of project proposals. In Rethinking Language Pedagogy from a Corpus Perspective, L. Burnard \& T. McEnery (eds), 74-90. New York: Peter Lang.

Volanschi, A. 2008. Étude et modélisation des phénomènes collocationnels: Implémentation dans un système d'aide à la rédaction en anglais scientifique. $\mathrm{PhD}$ dissertation, Université Paris Diderot.

Whitsitt, S. 2005. A critique of the concept of semantic prosody. International Journal of Corpus Linguistics 10(3): 283-305.

Xiao, R. \& McEnery, A. 2006. Near synonymy, collocation and semantic prosody: A cross-linguistic perspective. Applied Linguistics 27(1): 103-129.

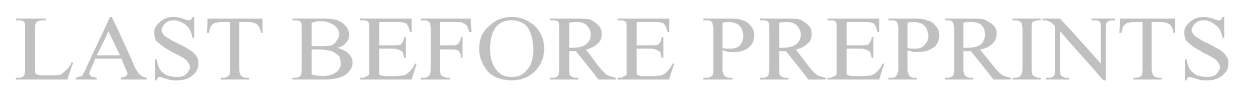

